\title{
A method of recording oviduct and uterine myoelectrical activity in gilts using implantable telemetry*
}

\author{
J. Woliński ${ }^{1}$, A. Zięcik², Z. Gajewski³ ${ }^{3}$ W. Korczyński ${ }^{1}$ \\ and R. Zabielski ${ }^{1,4}$ \\ ${ }^{I}$ The Kielanowski Institute of Animal Physiology and Nutrition, Polish Academy of Sciences \\ 05-110 Jabtonna, Poland \\ ${ }^{2}$ Institute of Animal Reproduction and Food Research, Polish Academy of Sciences \\ Tuwima 10, 10-747 Olsztyn, Poland \\ ${ }^{3}$ Department of Animal Reproduction, Faculty of Veterinary Medicine \\ Warsaw Agricultural University \\ Nowoursynowska 166, 02-787 Warsaw, Poland
}

(Received 20 June 2002; revised version 5 March 2003; accepted 4 April 2003)

\begin{abstract}
A method of telemetric recording of myoelectrical activity (EMG) in the female pig reproductive tract is described. In 10 gilts the telemetry implant was placed extraperitoneally between the abdominal muscle layers and connected with two or three bipolar silver electrodes sutured on different parts of the uterus and oviducts. The animals recovered from surgery quickly and without complications. The radio waves sent by the implant were collected and demodulated by a receiver and then recorded on a computer disk. Two-three $\mathrm{h}$ recording sessions were performed every 2-3 days. The electrodes collected EMG signals free of artifacts for 5-6 weeks after surgery. Off-line analysis of myometry and oviduct EMG activities showed no major differences from the activities measured earlier by conventional wire methods. In conclusion, a commercially available telemetry system can be used for reproductive tract myoelectric activity studies in pigs.
\end{abstract}

KEY WORDS: method, reproductive tract, electromyography, pig

\footnotetext{
* Supported by the State Committee for Scientific Research, Grant No. 5 06D 04714

${ }^{4}$ Corresponding author: e-mail: r.zabielski@ifzz.pan.pl
} 


\section{INTRODUCTION}

Radiotelemetry allows transformation of biological signals from the animal body into radio waves that can be received by a recording system placed at a distance from the animal's cage. Modern radiotelemetry applications require computer support for receiving, filtering, amplifying and storing the signal data for further analysis. So far, this technique has allowed successful registration of various body parameters like motion, electrocardiography, temperature, and blood pressure in unrestrained freely-moving animals (Kramer et al., 1993; Brooks et al., 1996, 1998; Deveney et al., 1998). Despite the development of in vitro techniques, chronic in vivo experiments are still important for understanding animal physiology and behaviour as well as in pharmacological studies. Developing telemetry techniques improves animal welfare, helps to collect signals under conditions close to normal physiological ones, and considerably reduces the number of animals used for studies (Brockway and Hassler, 1993). Recently, an implantable telemetry method using commercially available equipment was implemented in the electromyography studies of the gastrointestinal tract in weaned piglets (Gacsalyi et al., 2000). The aim of the present study was to adapt this technique for electromyography recording of the uterus and oviduct in gilts.

\section{MATERIAL AND METHODS}

\section{Electrode and implant preparation}

Silver bipolar needle electrodes were prepared according to Sarna et al. (1981) with our modifications. Silver electrode wires $(\varnothing 0.4 \mathrm{~mm}$, purity $99.98 \%)$ were soldered to $10-15 \mathrm{~cm}$ long stainless steel Teflon-coated multistrand wires (A-M System, No.7935, Carlsborg, USA), and fixed in a silicone base (Figure 1). The electrode base was made from two thin silicone sheets ( $\Sigma$ Sigma medical, No. 2079, Nanterre, France) and a nylon surgical mesh placed between silicone sheets and fixed with a silicone glue (Silastic ${ }^{\circledR}$ No. 891, Dow Corning, USA). The oviduct electrode base was semicircular (outer diameter, o.d. $5 \mathrm{~mm}$; Figure 1A), while the uterine electrodes had a flat base (Figure 1B). Three-channel telemetry transmitter implants for biopotential recording in large animals (TL10M3D70-EEE, weight $40 \mathrm{~g}$ ) were purchased from Data Sciences International (St. Paul, MN, USA). The electrode extension wires were soldered to the leads of a telemetry implant and the junctions were waterproofed with silicone. The electrodes and telemetry implants were sterilized in 2\% glutaraldehyde (Aldesan E, FChSP, Ząbki, Poland) for $2 \mathrm{~h}$ and washed with sterile saline immediately before implantation. 
A

B

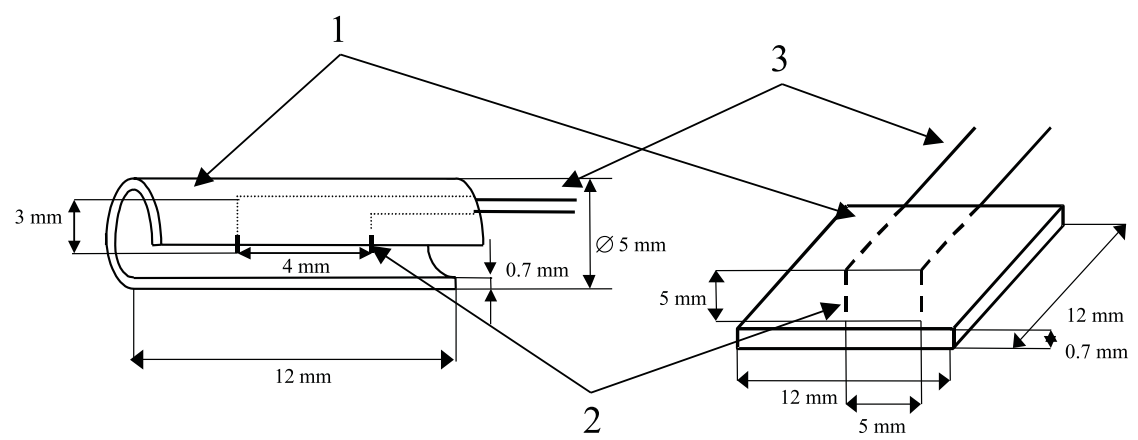

Figure 1. Scheme of oviduct (A) and uterus (B) electrodes; 1-silicone base, 2-silver electrode wires 3 -extension stainless steel wires connected to the implant leads

\section{Animals and surgery}

Ten gilts (Polish White, 70-90 kg body weight, BW) were obtained from a commercial piggery and allowed 6-7 days of adaptation before surgery. After premedication with azaperone (Stresnil, Janssen, Belgium), $8 \mathrm{mg} / \mathrm{kg} \mathrm{BW}$ intramuscularly (im) anaesthesia was induced with $4 \%$ halothane (Narcotan $0.01 \%$, Leciva, Czech Republic) and then maintained with 1.5-2\% halothane mixed with oxygen (2 1/min). Right-side laparotomy was performed, and the electrodes were sutured to the serosal layer in the middle part of the left oviduct (LO), right oviduct (RO) and the corpus of the uterus (CU) with nonabsorbable, noncapilary silk sutures (Sutramed 4-0, La Neuveville, Switzerland). In some gilts, one electrode was placed in the ampulla of the left oviduct and the other in the middle of the uterine horn. The peritoneum and the internal abdominal muscle layers were closed routinely, and the telemetry implant was fixed in a pocket made between the abdominal muscles to which a ground electrode was sutured. An antibiotic, amoxycillin trihydrate, $15 \mathrm{mg} / \mathrm{kg}$ BW (Clamoxyl ${ }^{\mathrm{TM}}$ L.A., Pfizer Ltd., UK) was given im after surgery and repeated after $48 \mathrm{~h}$. All experiments were performed in accordance with the "Guiding Principles for the Care and Use of Research Animals" and approval from the local ethics committee had been obtained.

\section{Recordings (equipment and settings)}

The gilts were kept in individual standard metabolic cages with feeding troughs and constant access to tap water. The animals received a standard diet for growing pigs ( $18 \%$ crude protein in dry matter) twice daily at 8.00 and 15.00 at a daily allowance of $4 \%$ of BW. The electromyographic signal was checked several times after surgery for 


\section{Telemetry recording system}

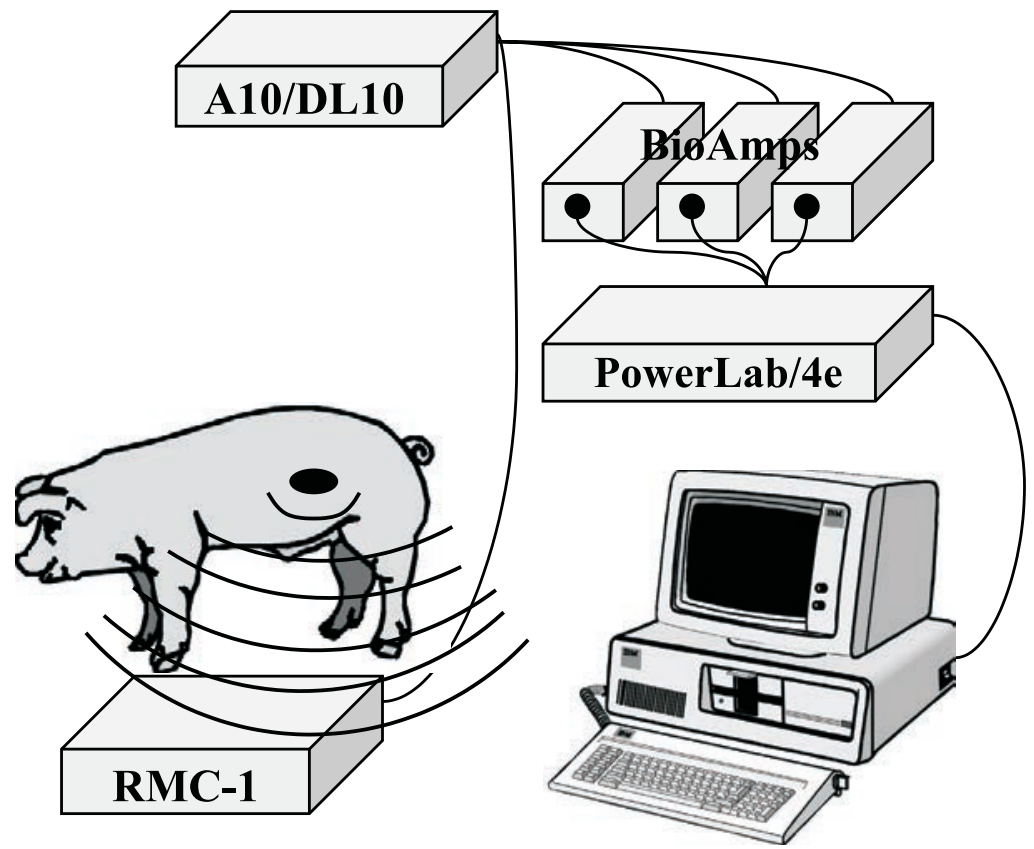

Figure 2. Telemetry system assembled for electromyography studies: RMC-1 - telemetry receiver; A10/DL10 - analog output; BioAmps and PowerLab/4e - filtering, amplifying and data acquisition system. Besides the waterproofed RMC-1 receiver, the recording unit is placed outside the animal room

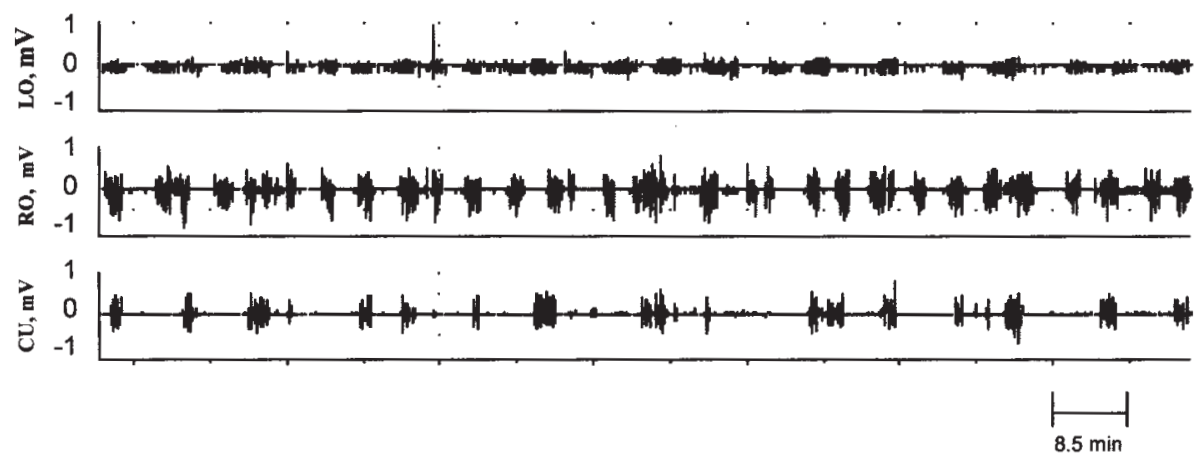

Figure 3. Typical recording of the myoelectrical activity of the left (LO) and right (RO) oviduct and the corpus of uterus (CU) in a gilt. Vertical bar shows the time scale (min) 


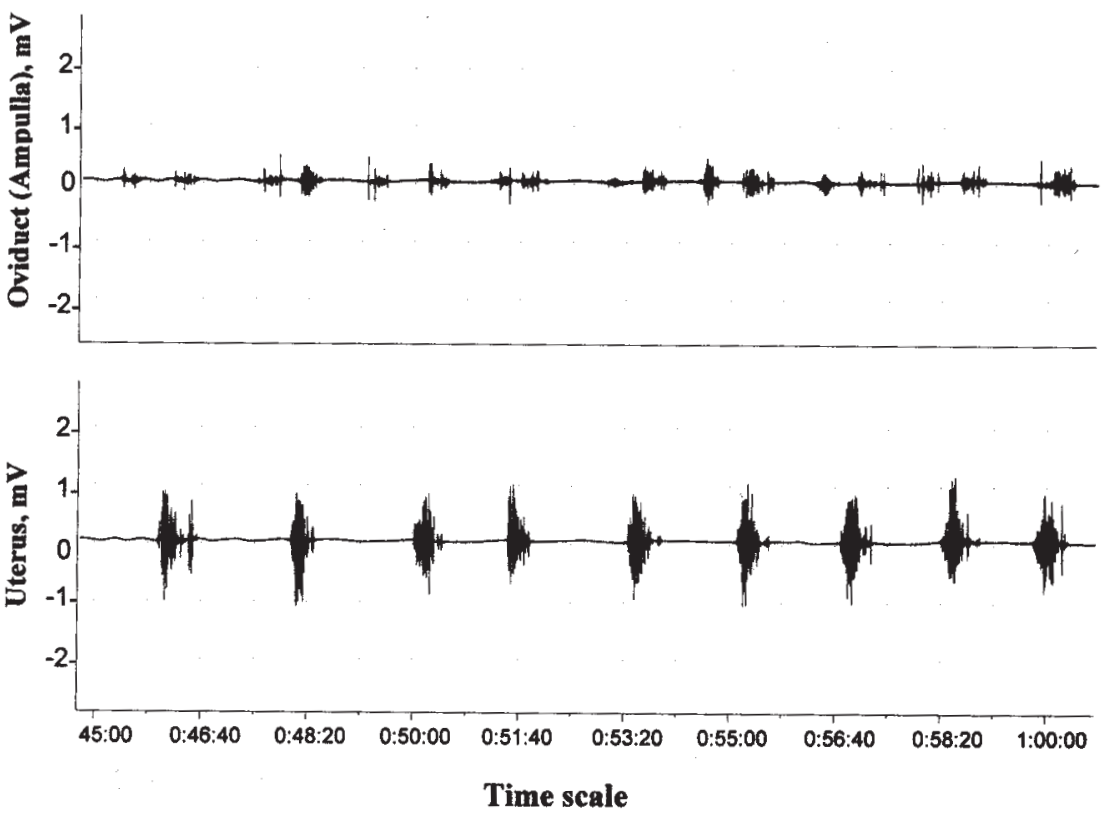

Figure 4. Electromyography activity recording of the oviduct ampulla (top) and uterus (bottom) in gilt at the end of the follicular phase of the estrous cycle. The cycle phase was distinguished by clinical examination after recording as well as by comparing with traces from the author's own database (Zięcik et al., 1992, 1993). Time (h:mm:ss) from the beginning of recording

signal quality, i.e. the number of injury potentials. Regular recordings began on day 10 and were performed for 2-3 $\mathrm{h}$ after morning feeding every two or three days.

The telemetry transmitter implant was kept off between recordings to spare battery life and was switched on with a magnetic key just before the recording session. The signals were received by an RMC-1 receiver (DSI) placed near the animal's cage and coupled to a DL10 analog output (DSI) - Figure 2. Each of three signal channels was filtered (high cut-off $50 \mathrm{~Hz}$, low-cut $10 \mathrm{~Hz}$ ) and amplified (BioAmp, ADInstruments, Melbourne, Australia). Sampling speed was set at 40 samples/s. The output from the DL10 was attenuated by soldering a $10 \mathrm{k} \Omega$ resistor between DL10 and each BioAmp, and a $100 \Omega$ resistor between the shield and "+" in front of each BioAmp so as not to overload the BioAmps. A four-channel PowerLab/4e (ADInstruments) unit and PC computer with Chart v.4.1 (ADInstruments) software were used to record, display and analyze the data. After two months, the animals were sacrificed by pentobarbital sodium overdose. The electrodes and corresponding wires were discarded, and the implants gently removed, carefully cleaned from the remaining tissues, sterilized with $2 \%$ glutaraldehyde solution and reused. The battery life allowed recording of 3 to 4 animals. 


\section{Quantification of the electromyography signal}

To discriminate between myometrial and other electrical activity, an EMG burst was defined as a series of fluctuations of electrical potential which had an amplitude in excess of $5 \mu \mathrm{V}$, a duration of longer than $3 \mathrm{~s}$ and was separated from any subsequent series by an interval of electrical quiescence of at least $5 \mathrm{~s}$. The appearance of any electrical activity after a silent period was assumed to be a new electrical burst. The following parameters were calculated using Chart off-line analysis software: duration of single spike (s), duration of activity and non-activity periods $(\mathrm{s})$, signal power (root mean square, RMS) $(\mathrm{mV})$, spike amplitude $(\mathrm{mV})$, mean frequency of single spike (MFSS) (spikes/30 min), mean frequency of burst (MFB) (bursts/30 min), and mean total duration of electrical activity (MTDEA) (s). Data are presented as means and their standard deviation.

\section{RESULTS}

The pigs recovered readily from the anaesthesia and were clinically healthy during the whole study. No training or adaptation period was necessary before the recordings since the pigs stayed in their own cages with no additional restraint or manipulation besides turning the implants on and off by the magnetic key and placing the receiver plate (RMC-1) near their cages. According to the producer's instructions, the maximum distance between the implant and receiver should not exceed $1 \mathrm{~m}$, though in our study we increased the distance up to $1.4 \mathrm{~m}$ without affecting the quality of the signal. Successful EMG recordings were obtained from each electrode site (Figure 3). After 5 to 6 weeks from surgery, the signal amplitude weakened and became full of artifacts due to connective tissue overgrowth between the serosa and electrodes. Table 1 presents the results of the off-line analysis of the oviduct and uterine myoelectrical activity. Figure 4 shows a representative EMG tracing that is identical to that normally recorded on the end of the follicular phase of the oestrus cycle in gilts by means of a classical wire method (Zięcik et al., 1992, 1993). The identification of cycle phases was based on comparison of the analyzed EMG parameters with those published previously by Zięcik et al. $(1992,1993)$ and clinical examination of the gilts after the recording sessions. The mean burst duration in the ampulla, analyzed off-line from the trace shown in Figure 4, was $30.5 \pm 2.4 \mathrm{~s}$, and the total duration of electrical activity was $736 \mathrm{~s}$. The same parameters recorded in the uterine horn were, respectively, $27.0 \pm 0.9$ and $520 \mathrm{~s}$. The MFB in the ampulla of the oviduct was 27 bursts $/ 30 \mathrm{~min}$, and that in the uterine horn was 21 bursts $/ 30$ min. However, the mean amplitude of spikes within a burst was significantly lower in the ampulla of the oviduct as compared to that in the uterine horn, $0.32 \pm 0.01$ vs $0.86 \pm 0.04 \mathrm{mV}$, respectively. The amplitude of some single spikes in the uterus was 4-8 times higher than in the oviduct (Figure 4). 


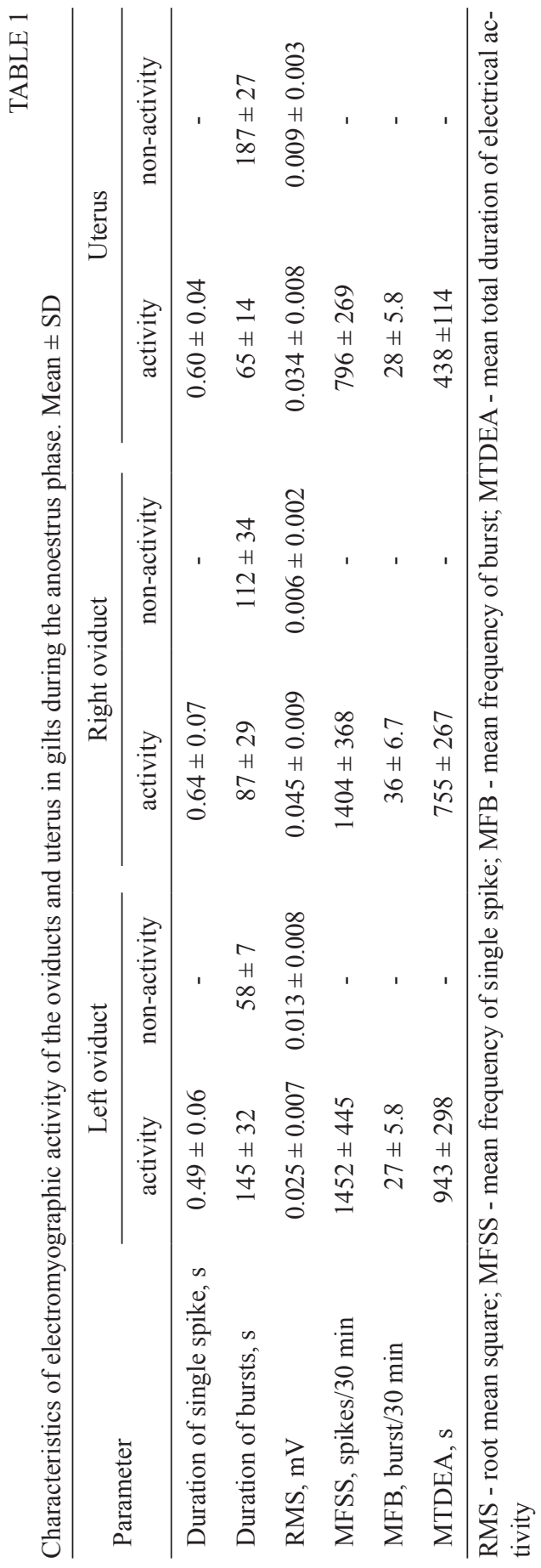




\section{DISCUSSION}

The present paper demonstrates the first application of implantable telemetry for recording of oviduct and uterine myoelectrical activity in gilts. The surgical procedure is relatively simple, like in cardiac (Kramer et al., 1993) and gastrointestinal (Gacsalyi et al., 2000) electromyographic telemetry studies. The greatest advantage over the traditional method is that the implant is placed between the abdominal muscles, thereby no wires and plugs extend from the skin, resulting in only minimal irritation of animals and negligible chance of inducing ascending inflammation. The recorded myoelectrical activity is similar to that earlier registered in gilts with a wire method (Zięcik et al., 1993). However, the duration of recording is limited in the present approach by the implant battery life (approximately 3 months of continuous recording) and computer disk capacity. It is also limited, like in the wire method, by connective tissue overgrowth in the sites of electrode implantation. Nevertheless, the electrodes functioned long enough to cover one entire estrous cycle, thus giving a chance to study myoelectrical activity in different cycle phases. This method has already been used for studies on reproductive tract motility and plasma LH and progesterone concentrations (Zięcik and Gajewski, unpublished data), and can be recommended as a powerful tool for oviduct and uterine physiology and pharmacology studies.

\section{CONCLUSIONS}

The method of wireless myoelectrography described here is a simple and reliable alternative to the traditional wire approach. It is based on a commercially available telemetry system and simple surgical procedures. Finally, it has a great advantage over the traditional wire method since animal restraint and human presence are not necessary during data recording. 


\section{REFERENCES}

Brockway B.P., Hassler C.R., 1993. Application of radiotelemetry to cardiovascular measurements in pharmacology and toxicology. In: H. Salem, S.I. Baskin (Editors). New Technologies and Concepts for Reducing Drug Toxicities. CRC Press Inc., Boca Raton, pp. 109-132

Brooks D., Horner R.L., Kozar L.F., Waddell T.K., Render C.L., Philipson E.A., 1996. Validation of a telemetry system for long-term measurement of blood pressure. J. Appl. Physiol. 81, 10121018

Brooks A., Aharoni Y., Degen A.A., Wright D., Young B., 1998. Estimation of energy expenditure from heart rate measurements in cattle maintained under different conditions. J. Anim. Sci. 76, 3054-3064

Deveney A.M., Kjellström A., Forsberg T., Jackson D.M., 1998. A pharmacological validation of radiotelemetry in conscious, freely moving rats. J. Pharmacol. Toxicol. Method. 40, 71-79

Gacsalyi U., Zabielski R., Pierzynowski S.G., 2000. Telemetry facilitates long-term recording of gastrointestinal myoelectrical activity in pigs. Exp. Physiol. 85, 239-241

Kramer K., van Acker S.A.B.E., Voss H.P., Grimbergrn J.A., van der Vijgh W.J.F., Bast A., 1993. Use of telemetry to record electrocardiogram and heart rate in freely moving mice. J. Pharmacol. Toxicol. Method. 30, 209-215

Sarna S., Stoddard C., Belbeck L., McWade D., 1981. Intrinsic nervous control of migrating myoelectric complexes. Amer. J. Physiol. 241, G16-G23

Zięcik A.J., Gajewski Z., Jedruch J., Barcikowski B., 1993. Effect of human chronic gonadotropin on myometrial electrical activity in the pig. Anim. Reprod. Sci. 31, 131-139

Zięcik A.J., Jedlinska M., Rzucidlo J.S., 1992. Effect of estradiol and progesterone on myometrial LH/hCG receptors in pigs. Acta Endocrinol. 127, 185-188

\section{STRESZCZENIE}

\section{Metoda rejestracji aktywności mioelektrycznej jajowodu i macicy u loszek z użyciem teleme- trycznych implantów}

Opisano metodę telemetrycznej rejestracji aktywności mioelektrycznej (emg) jajowodu i macicy loszek. U 10 loszek nadajnik telemetryczny umieszczono pozaotrzewnowo w kieszonce pomiędzy mięśniami brzusznymi i połączono z 2-3 srebrnymi dwubiegunowymi elektrodami naszytymi na macicy i jajowodach. Po operacji zwierzęta szybko i bez komplikacji powracały do zdrowia. Wysyłany przez implant, w postaci fali radiowej, sygnał był demodulowany i zapisywany na komputerze. Dwu-trzygodzinne rejestracje emg prowadzono w odstępach 2-3 dniowych. Elektrody odbierały czysty, bez artefaktów sygnał przez 5-6 tygodni po operacji. Analiza rejestrowanego sygnału nie wykazała istotnych różnic w porównaniu z wcześniejszymi zapisami wykonanymi przy użyciu konwencjonalnych metod z użyciem kabli. Podsumowując, zestaw do rejestracji telemetrycznej może służyć do badań aktywności mioelektrycznej układu rozrodczego loch. 